\title{
The Impact of International Capital Flows on Central and Eastern European Countries' Investments, Savings, Consumption, and Current Accounts
}

\author{
Laura Vilutiene, Daiva Dumciuviene
}

Kaunas University of Technology

K. Donelaicio st. 73, LT-44029, Kaunas, Lithuania

E-mail.laura.vilutiene@ktu.lt; daiva.dumciuviene@ktu.lt

cross'ref $\mathrm{http}: / / \mathrm{dx}$.doi.org/10.5755/j01.ee.31.4.24855

Capital flows have been analysed from various perspectives and yet no consensus has been reached about the impact of international capital flows on national economies. The main aim of this paper is to present the theoretical aspects of the effect of international capital flows on national economies, and to analyse the impact of international capital flows on Central and Eastern European (CEE) countries'domestic savings, investments, consumption, and current accounts. During the investigation, the latest studies on international capital flows were reviewed and systemised, 11 CEE countries' main indicators from across a 10-years period were collected, and computed coefficients, which represent the change associated with a variation in clusters' capital inflows, equal to 1 percent change of GDP, were analysed. The analyses conducted show that capital flows have an impact on countries' economies. The main findings are: first, domestic savings and consumption are seen to have been more strongly associated with capital inflows than investments in developed countries. Second, the relationship between investments, domestic savings, consumption and one inflow in portfolio flows would be negative, in both highly developed countries and emerging market countries. Third, where positive inflows in net and gross capital are concerned, foreign direct investments would have an insignificant positive impact on current accounts in highly developed countries and developed countries but a negative impact in emerging market countries. By achieving economic growth dynamics within a specific country, a wide evaluation of a country's capital flows can be performed, and control of capital flows gained, by applying different assessment models.

Keywords: International Capital Flows; Impact; Economic Growth; Central and Eastern European Countries; Countries' Economies.

\section{Introduction}

Globalization of economic activity, integration of financial markets, and increased capital mobility have been key factors in the world economy in recent decades. The main dimension of economic globalization is financial globalization and, in particular, cross-border capital flows. The global crisis (2008-9) had a significant impact on countries' economies and revived debates about the desirability of financial integration in both advanced economies and emerging markets. At present, there are reports of new and upcoming crises, which provide a strong, fresh impetus for the evaluation of the impact of international capital flows on a country's economy.

In recent decades, a huge inflow of capital to developing countries has occurred. According to World Bank statistics, annual private capital inflows to emerging markets surged from around USD 50 billion in 1990 to almost USD 1.3 trillion in 2018. On the one hand, increased inflow to a country's economy may not only raise investment and consumption but also promote the growth of the economy. On the other hand, systematic inflow of foreign capital to emerging economies may lead to their over-reliance on external financing.

During and after the global financial crisis period, several publications about and research on this theme emerged. Bussiere and Fratzscher (2008) have noted that "no empirical evidence has yet emerged for the existence of robust positive relationships between financial openness and growth". By contrast, Klein and Olivei (2008) found significant and positive effects of open capital accounts on financial depth and economic growth.

Literature analyses suggest that the relationship between capital flows and investment is complex. It can depend on various aspects, such as the nature of the capital flows, the investment climate and integration of domestic economies into global capital markets. Review of the literature reveals that there is no consensus on the relationship between international capital flows and economic growth, nor on the most appropriate models with which to assess the effect of international capital flows on a country's economic development. Many studies have focused on the role of foreign direct investments (FDIs) in the way that emerging markets grow, or on analysing one specific area such as domestic savings, but there are few analyses related to the impact of international capital flows on countries' investments, domestic savings, consumption and current accounts taken altogether. To fill this gap, this article addresses the scientific problem formulated as follows: what is the impact of international capital flows on countries' investments, domestic savings, consumption and current accounts?

The focus of this article is countries' international capital flows. The main aim of this paper is to present the theoretical aspects of the effect of international capital flows on a country's economy and to analyse the impact of 
international capital flows on Central and Eastern European (CEE) countries' economies (i.e. how international capital flows can affect countries' investments, domestic savings, consumption and current accounts). Eleven CEE countries that became EU Member States during the period 2004-7 were included. The period under analysis is 2009-18. The novelty of this paper is that both net and gross capital flows were taken into account and countries were analysed in the context of the dynamic between several areas: investments, domestic savings, consumption and current accounts.

The research reveals that capital flows have an impact on countries' economies. A wide evaluation a country's capital flows can be performed to obtain a broad view, take control of a country's capital flows and make the right decisions for the country's economic development.

This paper is organized as follows. Analysis of the existing studies of international capital flows and performance measurement are presented in the first part of this article. The second part of this article covers the methodology and the third part presents the results of the analysis. Conclusions and suggestions for future research are presented at the end of this paper.

\section{Existing Studies on Capital Flows and their Effect on the Economy}

In some research studies the argument is put forward that capital flows have a positive impact on a country's economy and positively affect its growth dynamic. Edwards and Rigobon (2009), Carkovic and Levine (2002) and Durham (2004) contend that capital flows act as a catalyst for economic development, and debates continue on the relationship between capital flow and economic growth in host countries and especially in developing economies.

However, other studies oppose the above perspective. For example, Kyaw and Macdonald (2009) conclude that the results are inconclusive: in existing studies on private capital flows' relationship with economic growth, one main variable is analysed - capital flow - which is expressed as capital flow in aggregate or as a FDI, and the correlation between different forms of capital flows and economic growth remains obscure. In addition, most of the empirical studies on the effect on growth of private capital flows in developing countries exist mainly for FDI, and there are few analyses from the perspectives of different income classification groups. According to Kyaw and Macdonald (2009), "relatively little is known about whether and how the impact of capital flows may vary across developing countries in different income categories, such as lowincome (LI), lower-middle-income (LMI) and uppermiddle-income (UMI) groups". Bussiere and Fratzscher (2008) conducted analyses on 45 advanced economies and emerging markets between 1980 and 2002 and found that financial openness may promote growth in the short term but not in the medium to long term.

Recent economic growth theories are present in the literature, most of which argue that capital flows can increase national economic growth. Lucas (1988, 1990), Romer (1986, 1990, 1993), Mankiw et al. (1992), Pack (1994) and Velde and Xenogiani (2007) have proposed new endogenous growth theories that seek to incorporate human capital into production functions and to enable the externalization of knowledge. These researchers believe that, in such a way, capital flows can be growth-enhancing.

Levine (2001), Hermes and Lensink (2003), Harrison et al. and Kyaw and Macdonald (2009) propose that "FDI can contribute to growth through technology transfer, diffusion and spillover effects. By facilitating information acquisition (reflecting technology), and hence resource allocation and growth, via increased market liquidity, portfolio flows can play an important role in promoting growth by enhancing market efficiency and boosting productivity growth". In the light of this, it can be concluded that international capital can transfer ideas from industrial to developing countries and thus increase productivity in the long term.

In recent years, the analysis of gross flows has become more and more popular and it provides a larger scale of gross flows than net flows. Rey (2015) and Borio and Disyatat (2015) agree that gross financial flows are crucial for assessing financial stability and credit conditions, while net flows (mirroring current account imbalances) are crucial for the sustainability of net international investment positions.

Wei (2018) has addressed this topic with a focus on cross-border capital flow, which has risen substantially relative to world GDP. According to Wei, capital flows can provide new opportunities for economies to improve their efficiency and increase trade activities, and, at the same time, they can be a source of economic instability, making financial globalization less beneficial. Klein and Olivei (2008) found significant and positive effects of open capital accounts on financial depth and economic growth in a crosssection of countries in the periods 1986-95 and 1976-95.

Countries often take different responsive actions, their decisions informed by their particular interests during crises or their attempts to achieve economic stability in their country. Both, Forbes et al. (2015) and Alfaro and Chauvin (2017) have provided examples of such a situation, including the following: "Brazil applied a series of capital control measures to stem the flow of capital to manage the risk between 2008 and 2013. China, in April 2018, declares to the world that it would implement several financial globalization policies. e.g., open up China's financial services sector".

\section{Measurement of Capital Flows: Why it is Important?}

The terms like "capital flow management", "capital flow control" and "capital flow measures" (CFMs) have been increasingly used by economists and policymakers in recent years. This is because of the need to rapidly identify and address the negative effects of large and volatile capital flows.

Still, the question remains: why it is so important to control capital flows? In recent publications, a number of scenarios have been provided and different types of capital flow measures evaluated. Various theoretical papers have been prepared on how CFMs can increase social welfare and a country's economic sustainability. However, there is very little if any consistency between publications on how capital flows are measured. Forbes et al. (2015) have suggested two types of CFMs: (1) "capital controls or any types of restrictions on cross-border financial activity which discriminate based on residency and (2) "macroprudential 
measures, which do not discriminate and is based on residency, but relate to cross-border or foreign currency exposure and lending".

Other types of CFMs and consequences of controlling capital flows that have been suggested are presented in Table 1.

Table 1

Types of Capital flow Measures and Consequences of Controlling Capital Flows

\begin{tabular}{|l|l|l|}
\hline \multicolumn{2}{|c|}{ Types of capital flow measures } & $\begin{array}{c}\text { Consequences of } \\
\text { controlling capital } \\
\text { flows }\end{array}$ \\
\hline $\begin{array}{l}\text { Limits on foreign } \\
\text { ownership of } \\
\text { domestic } \\
\text { companies' assets }\end{array}$ & $\begin{array}{l}\text { Limits on borrowing } \\
\text { from abroad and } \\
\text { offshore entities } \\
\text { (offshore } \\
\text { commercial } \\
\text { borrowing included) }\end{array}$ & $\begin{array}{l}\text { A volume of capital } \\
\text { flows reduced }\end{array}$ \\
\hline $\begin{array}{l}\text { Limits on } \\
\text { purchase of } \\
\text { foreign assets }\end{array}$ & $\begin{array}{l}\text { Limits on banks' } \\
\text { lending and its } \\
\text { position }\end{array}$ & $\begin{array}{l}\text { Financial instability } \\
\text { in emerging } \\
\text { economies stabilized }\end{array}$ \\
\hline $\begin{array}{l}\text { Taxes and reserve } \\
\text { requirements on } \\
\text { capital inflows, } \\
\text { liabilities and } \\
\text { transactions }\end{array}$ & $\begin{array}{l}\text { Special licensing on } \\
\text { FDI and other } \\
\text { financial } \\
\text { transactions }\end{array}$ & $\begin{array}{l}\text { Composition of } \\
\text { capital flows } \\
\text { changed }\end{array}$ \\
\hline $\begin{array}{l}\text { Limits on the } \\
\text { maturity structure } \\
\text { of liabilities and } \\
\text { assets }\end{array}$ & $\begin{array}{l}\text { Limits on off- } \\
\text { balance-sheet } \\
\text { activities }\end{array}$ & $\begin{array}{l}\text { An economic crisis } \\
\text { avoided in a country }\end{array}$ \\
\hline $\begin{array}{l}\text { Regulations } \\
\text { resulting from } \\
\text { specific trade } \\
\text { disputes }\end{array}$ & $\begin{array}{l}\text { Requirements on } \\
\text { asset classification } \\
\text { and provision }\end{array}$ & $\begin{array}{l}\text { The more } \\
\text { independent } \\
\text { monetary policy } \\
\text { allowed in a country }\end{array}$ \\
\hline $\begin{array}{l}\text { Limits on asset } \\
\text { acquisition }\end{array}$ & $\begin{array}{l}\text { Dampen real estate } \\
\text { prices }\end{array}$ & $\begin{array}{l}\text { The stable economy } \\
\text { moved towards }\end{array}$ \\
\hline $\begin{array}{l}\text { Central bank's } \\
\text { instruments with } \\
\text { longer maturity }\end{array}$ & $\begin{array}{l}\text { Transactions by the } \\
\text { central bank or } \\
\text { government }\end{array}$ & $\begin{array}{l}\text { Real exchange rate } \\
\text { pressures reached }\end{array}$ \\
\hline $\begin{array}{l}\text { Arrangements } \\
\text { with non-resident } \\
\text { financial } \\
\text { institutions }\end{array}$ & $\begin{array}{l}\text { Changes in } \\
\text { macroprudential and } \\
\text { capital control } \\
\text { regulations and }\end{array}$ & $\begin{array}{l}\text { Country's economic } \\
\text { growth reached }\end{array}$ \\
\hline
\end{tabular}

Source: after literature analyses, prepared by authors.

Bluedorn et al. (2013) write that "increased exploring of measures of capital flow can be caused by limiting exchange rate appreciation, reducing portfolio inflows, providing greater monetary policy independence, reducing inflation, reducing volatility, and/or reducing specific measures of financial fragility (such as bank leverage, credit growth, asset bubbles, foreign-currency exposure, or shortterm liabilities)". According to Bluedorn et al., CFMs could help stabilize a country's economy when major capital flows' volatility is caused by external factors.

Edwards and Rigobon (2009) analysed capital controls on inflows, exchange rate volatility and external vulnerability and found that "tightening of capital controls increases the unconditional volatility of the exchange rate, but makes it less sensitive to external shocks". Edwards and Rigobon contend that capital controls on inflows are effective, in the sense of helping to reduce the impact of external shocks on the nominal exchange rate. Edwards and Rigobon focused on an extensive assessment of the effectiveness of macroprudential policies (MPPs) in reducing foreign capital, and an examination of related spillover risks, and thus potential costs.

Qureshi et al. (2011) and Beirne and Friedrich (2014) present correlations between the foreign exchange measure and various types of CFMs such as banking flows (\% of GDP), portfolio debt flows (in \% of GDP) and both types of flows as portfolio share measures. They argue that MPP measures do not strongly affect capital flows (finding that all four regression lines are flat or only minimally downward sloping) and that the effect of MPPs is rather limited on capital inflow in the average-level country.

Beirne and Friedrich (2014) have analysed the effectiveness and risks of MPPs in managing international capital flows; they write that "it is worth noting that while capital flows can have substantial positive effects on economies concerning to the promotion of growth and employment, there is also ample evidence to suggest that foreign capital inflows can contribute to the creation of credit booms, lead to over-indebtedness, and facilitate maturity and currency mismatches. To mitigate the negative effects associated with capital inflows, MPPs can be used. These measures (unlike capital controls, which differentiate between residents and non-residents of a country) apply to all participants of the financial system". The effectiveness of MPPs is inversely related to cost measures in the domestic banking system.

On the one hand, we can acknowledge the importance of the assessment of the impact of capital controls and macroprudential measures; on the other hand, in doing so we encounter difficulties related to selection bias and data availability. Every country is different and different methods can be used in economies; therefore, it is hard to develop one model that is suitable for all countries. Furthermore, analyses have shown that there are interesting differences between countries that apply capital controls and macroprudential measures in their economy evaluation countries that do not. Countries need to be prepared to adopt policies in response to changes of key macroeconomic variables, which are often targeted at control and macroprudential measures. Forbes et al. (2015) argue that such challenges are not only hypothetical and should be taken into account during assessment of CFMs' impact. According to Forbes et al., "macroprudential measures related to international exposures can significantly improve measures linked to financial fragilities, such as bank leverage, inflation expectations, bank credit growth, and exposure to portfolio liabilities. Increased controls on capital inflows can reduce private credit growth (although this effect, as well as that for portfolio liabilities, appears to fade and reverse after six months)".

Forbes et al. proposed that CFMs do not have a significant effect on other macroeconomic variables and financial market volatilities during the short and medium term, such as equity indices, inflation, interest rate differentials or the volatility of exchange rates, portfolio flows or interest-rate differentials. At the same time, CFMs have restricted effectiveness in achieving two of their primary goals: reducing exchange rate appreciation and net capital inflows. Forbes et al. found major changes in capital controls, which received more attention from investors. They concluded that "major changes in inflow controls can also cause a significant increase in capital flow volatility and 
Laura Vilutiene, Daiva Dumciuviene. The Impact of International Capital Flows on Central and Eastern European ...

translate into no consistent, significant, or economically meaningful impact on the real exchange rate".

After review of the literature, we conclude that studies of capital control usually do not include all costs (e.g. gross and net flows in one analysis) and that, seeking to properly assess the economic situation in a country, these costs should be included in evaluations.

\section{Analysis of International Capital Flows in CEE Countries}

In this section we analyse international capital flows in CEE countries' economies, how they can affect domestic savings, investments, current accounts and consumption, and their economic impact.

\section{Methods}

During the investigation, the latest studies on international capital flows and their effect on countries' economies were reviewed and systemised.

Research gap: Data on 11 CEE countries - Bulgaria, Croatia, Czech Republic, Estonia, Lithuania, Latvia, Hungary, Poland, Romania, Slovak Republic, Slovenia were collected and computed. These countries were selected for the following reasons:

- they were European Union Member States during the period 2004-7 and the newest of the Member States;

- they were appointed to one CEE region;

- their involvement in the EU affected long-standing EU Member States' investments (new and expanding opportunities);

- their historical developments were similar - they were part of the socialist bloc, which had a significant impact on their economies and national growth

- they were seeking to avoid further economic crises in the region.

Analyses were conducted for the 10-year period of 2009-18 and were developed on the assumption that the impact of international capital flows on a country's economic growth depends on the level of that country's economic development. For this reason, CEE countries were divided into three clusters, according to several variables (see Table 2). In addition, the evaluation of one EU region may provide insight into the economic situations of other regions because each EU region can have an impact on the others owing to their interconnection and integration.

Table 2

Variables Used in the Analyses for Countries' Similarities Foundation

\begin{tabular}{lll}
$\begin{array}{l}\text { Name of } \\
\text { the } \\
\text { variable }\end{array}$ & \multicolumn{1}{c}{ Description } & Measurement \\
\hline \multicolumn{3}{c}{ Countries' economic size } \\
\hline $\begin{array}{l}\text { GDP- } \\
\text { per_capit } \\
\text { a }\end{array}$ & $\begin{array}{l}\text { Gross Domestic Product of } \\
\text { the country, related to the } \\
\text { population }\end{array}$ & US Dollars at current prices \\
\hline & \multicolumn{2}{c}{ Investments } \\
\hline $\begin{array}{l}\text { GDP_gro } \\
\text { ss }\end{array}$ & $\begin{array}{l}\text { Gross capital formation } \\
\text { GDP_fix } \\
\text { ed }\end{array}$ & $\begin{array}{l}\text { Gross fixed GDP } \\
\text { formation }\end{array}$ \\
\hline & \multicolumn{2}{c}{ International trade } \\
\hline
\end{tabular}

\begin{tabular}{|c|c|c|}
\hline $\begin{array}{l}\text { Name of } \\
\text { the } \\
\text { variable }\end{array}$ & Description & Measurement \\
\hline export & $\begin{array}{l}\text { Exports of goods and } \\
\text { services }\end{array}$ & $\%$ of GDP \\
\hline import & $\begin{array}{l}\text { Imports of goods and } \\
\text { services }\end{array}$ & $\%$ of GDP \\
\hline trade & $\begin{array}{l}\text { Exports plus imports of } \\
\text { goods and services }\end{array}$ & $\%$ of GDP \\
\hline $\begin{array}{l}\text { Current_ } \\
\text { account }\end{array}$ & Current account balance & $\%$ of GDP \\
\hline FDI & Foreign direct investments & $\%$ of GDP \\
\hline \multicolumn{3}{|c|}{ Macroeconomic conditions } \\
\hline Infliation & Consumer price index & $\begin{array}{l}\% \text { average of } 10 \text { years } \\
\text { period }\end{array}$ \\
\hline \multicolumn{3}{|c|}{ Human capital } \\
\hline $\begin{array}{l}\text { Human_c } \\
\text { apital }\end{array}$ & Human Capital Index & Total \\
\hline \multicolumn{3}{|c|}{ Technological knowledge intensity } \\
\hline $\begin{array}{l}\text { R\&I } \\
\text { level }\end{array}$ & $\begin{array}{l}\text { Level of Research and } \\
\text { Innovation performance }\end{array}$ & $\begin{array}{l}\text { Regarding EU list and EU } \\
\text { average (equal to } 47,86 \text { ) }\end{array}$ \\
\hline
\end{tabular}

Indicators, provided in Table 2, were selected from the European Union's Sustainable development in the European Union - 2015 monitoring report of the EU Sustainable Development Strategy (2015) and based on Próchniak's (2006) review of empirical studies on economic growth determinants. The determinant 'technological knowledge intensity' was selected based on the European Commission's Research and Innovation Performance in the EU: Innovation Union progress at the country level (2014).

The terminology and defined indicators used in the analyses for clusters' capital flows are provided in Table 3. Terminology and indicators were selected following Forbes and Warnock (2012).

Table 3

Terminology Used in the Analyses

\begin{tabular}{ll}
\hline & Used terminology \\
\hline \multirow{3}{*}{ Gross capital inflows } & The sum of: \\
& - inflows of direct investment \\
& - portfolio inflows \\
& - other inflows \\
\hline \multirow{3}{*}{ Gross capital outflows } & The sum of: \\
& - outflows of direct investment \\
& - portfolio outflows \\
& - other outflows \\
\hline \multirow{3}{*}{ Gross capital flows } & The sum of: \\
& - gross capital inflows \\
& - gross capital outflows \\
\hline \multirow{3}{*}{ Net capital flows } & The subtraction of: \\
& - gross capital inflows \\
& - gross capital outflows \\
\hline
\end{tabular}

Adapted from Forbes and Warnock (2012), prepared by authors

The descriptive statistics of each variable are presented in Table 4. K-means algorithm was applied for countries' clustering. Selected countries' data were collected and computed coefficients, which represent the change associated with variations in clusters' capital inflows equal to 1 percent change of GDP, were analysed.

\section{Analyses}

Descriptive statistics of each indicator (see Table 4) and descriptive statistics of the selected countries (see Table 6) were generated. The biggest gap between the selected 
countries was in the GDP per capita. The analyses show that the standard deviation for this indicator is 4501.99: it varies from 7648.01 (Bulgaria) to 23533.06 (Slovenia) and is positively skewed. The economic growth of the country increases international capital flows. Observation of GDP per capita of the country helps to catch up the gravitational effect. This determinant is very important for the marketseeking multinational enterprises (MNEs), because they have a motive to invest in the country, which has high GDP per capita growth and the market size of which is growing.
The investment indicators (gross capital formation and gross fixed capital formation) deviate around the mean. The highest value belongs to the Czech Republic and the lowest value to Lithuania. Additionally, it should be mentioned that the skewness of the indicator gross capital formation is negative and the distribution is skewed to the left.

The lowest trade values of selected countries belong to Romania, Croatia and Poland, and the highest belong to the Slovak Republic, Hungary, Estonia and Lithuania.

Descriptive Statistics of the Selected Countries

\begin{tabular}{|c|c|c|c|c|c|c|c|}
\hline & Mean & Stand. dev. & Median & Min & $\operatorname{Max}$ & Skewness & Kurtosis \\
\hline \multicolumn{8}{|c|}{ Countries'economic size } \\
\hline GDP_per_capita & 15282.94 & 4501.99 & 14993.39 & 7648.01 & 23533.06 & 0.08 & 0.18 \\
\hline \multicolumn{8}{|c|}{ Investments } \\
\hline GDP_gross & 22.71 & 2.43 & 22.77 & 18.44 & 26.33 & -0.09 & -0.66 \\
\hline GDP fixed & 22.08 & 2.36 & 21.95 & 18.53 & 25.81 & 0.12 & -1.02 \\
\hline \multicolumn{8}{|c|}{ International trade } \\
\hline export & 66.10 & 16.88 & 73.82 & 37.93 & 88.60 & -0.35 & -1.19 \\
\hline import & 64.29 & 14.68 & 67.89 & 41.12 & 86.88 & -0.25 & -0.98 \\
\hline trade & 130.39 & 31.47 & 141.71 & 79.04 & 175.48 & -0.31 & -1.11 \\
\hline current_account & -0.20 & 1.79 & -0.21 & -3.25 & 2.76 & -0.07 & -0.33 \\
\hline FDI & 2.21 & 1.52 & 2.33 & -1.17 & 4.06 & -1.03 & 1.37 \\
\hline \multicolumn{8}{|c|}{ Macroeconomic conditions } \\
\hline infliation & 1.86 & 0.53 & 1.76 & 1.16 & 2.97 & 0.98 & 0.60 \\
\hline \multicolumn{8}{|c|}{ Human capital } \\
\hline human capital & 0.72 & 0.05 & 0.72 & 0.60 & 0.79 & -0.90 & 1.67 \\
\hline \multicolumn{8}{|c|}{ Technological knowledge intensity } \\
\hline R\&I level & 21.22 & 7.17 & 20.47 & 11.49 & 31.88 & 0.04 & -1.44 \\
\hline
\end{tabular}

It is interesting to note that all international trade groups' indicators are skewed negatively. Most of the countries' current account balances are negative as well, which also means that the international transfers of capital are imbalanced. Inflation deviates a little from country to country and is skewed positively. The lowest inflation belongs to Slovenia and the Slovak Republic and the highest belongs to Hungary and Romania. The research and innovation levels of the selected countries varies from 11.49 to 31.88 . The average EU level is 47.86 , which means that CEE countries invest less than others in the research and innovation sector.

Seeking to divide the most similar countries into clusters, a K-means algorithm was applied, as suggested in the literature - this algorithm uses within-cluster variation and is one of the simplest non-hierarchical clustering methods. The data were segmented and within-cluster variation was minimized.

A K-means algorithm allows freedom to decide how many clusters can be created. We chose to divide the 11 CEE countries into 3 clusters (see Table 5). The most similar and highly developed countries were the Czech Republic and Slovenia (cluster 1) and the lowest-level emerging market countries were Bulgaria and Romania (cluster 3). The remaining developing countries formed cluster 2 .
Table 5

Clusters of the Selected Countries

\begin{tabular}{lll}
\hline Cluster 1 & Cluster 2 & Cluster 3 \\
\hline & Croatia & \\
& Estonia & \\
Czech Republic & Lithuania & Bulgaria \\
Slovenia & Latvia & Romania \\
& Hungary & \\
& Poland & \\
& Slovak Republic & \\
\hline
\end{tabular}

Source: prepared by authors

Figure 1 presents the dynamic of GDP annual growth per clusters in the period 2009-18. The greatest rise in GDP was in cluster 2 , from $-8.63 \%$ to $4.17 \%$ in the period 2009 2011, which was after the crisis period ended. From 2012 all clusters displayed an indicator of incremental growth. During the final years (2017-18) growth slowed down across clusters 1 and 2. According to banks' prognoses, GDP growth will be around 1.0-1.5 percentage points less in the year 2020 than it was in 2018. This is attributable to staff shortages, demography, declining investment and decreased export. 
Laura Vilutiene, Daiva Dumciuviene. The Impact of International Capital Flows on Central and Eastern European ...

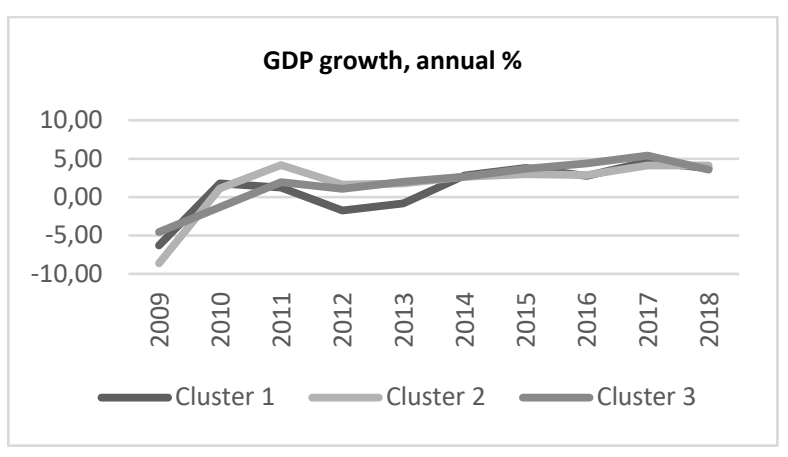

Figure 1. GDP Annual Growth

Source: World Bank, Global Development Finance: Country Tables and sources, period 2009-18. Prepared by authors.

Furthermore, analyses were conducted of the created clusters' capital flows variations.

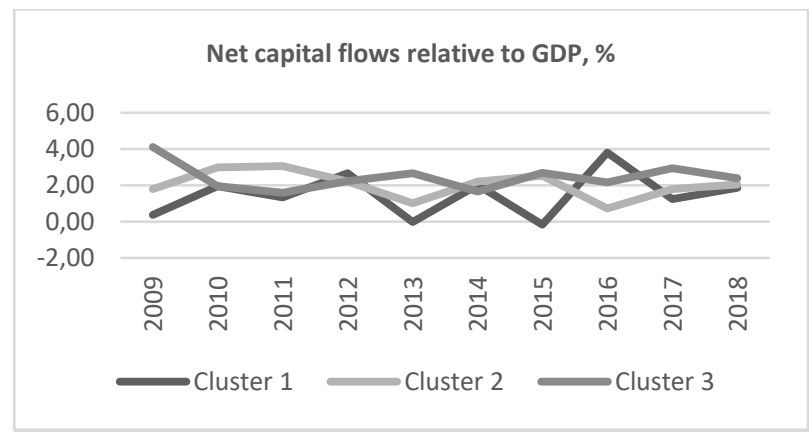

Figure 2. Percent of net Capital Flows Relative to GDP

Source: World Bank, Global Development Finance: Country Tables, period 2009-18. Prepared by authors.

Figure 2 presents the percentage of net capital flows relativeness to GDP (data for all three clusters). The dynamic of net capital flows to GDP in cluster 1 (which consists of the Czech Republic and Slovenia) fluctuates greatly; in 2009-10, that of cluster 3 (Bulgaria and Romania) was falling while that of cluster 2 was growing. During the final years (2017-18), the relativeness of net capital flows to GDP percentage increased in clusters 1 and 3 and decreased in cluster 2. Also, from 2017 to 2018 cluster 3's relativeness was highest $(2.4 \%$; that of clusters 1 and 2 was $<2 \%$ ).

During the analyses of capital flows, both net and gross capital flows were taken into account. Gross capital flows are larger and much more volatile relative to net capital flows. Table 6 presents the minimum, maximum, median, mean, and standard deviation values for the net and gross capital flows for all CEE countries' and Lithuania's economies for the sample period.

The gross flows show that the crisis period (2008-9) led to a massive temporary - rather than permanent - change in capital flows in Central European economies. Analysis of net flows indicates that the underlying structure changed too.

The impact of the clusters' capital flows on investment, domestic savings, consumption and current accounts was evaluated and is presented as follows:

- each cluster's average sum of GDP (billion US dollars) for the 10-year period was estimated;

- average sums of investments, domestic savings, consumption and current accounts of each cluster (billion US dollars) for the 10-year period were calculated;

- $\quad$ average sums of the net and gross capital flows, FDIs and portfolio investments of each cluster (billion US dollars) for the 10-year period were calculated;

- the percentage of investments, domestic savings, consumption and current accounts of each cluster in net and gross capital flows, FDIs and portfolio investments were calculated;

- changes to net and gross capital flows, FDIs and portfolio investments if GDP increased/decreased by $1 \%$ were estimated;

- the percentage of investments, domestic savings, consumption and current accounts of each cluster in net and gross capital flows, FDIs and portfolio investments after the above GDP changes were estimated;

Table. 6

Descriptive Statistics of Capital FLows

\begin{tabular}{|c|c|c|c|c|c|c|c|c|c|c|c|}
\hline \multirow{5}{*}{$\begin{array}{c}\text { Cluster } \\
1\end{array}$} & \multirow{5}{*}{$\begin{array}{l}\text { Czech Republic } \\
\text { Slovenia } \\
\text { Average of cluster }\end{array}$} & \multicolumn{5}{|c|}{ Net capital flows } & \multicolumn{5}{|c|}{ Gross capital flows } \\
\hline & & Min & Max & Median & Mean & $\begin{array}{l}\text { std. } \\
\text { dev. }\end{array}$ & Min & Max & Median & Mean & $\begin{array}{l}\text { std. } \\
\text { dev. }\end{array}$ \\
\hline & & -1.845 & 8.104 & 3.277 & 3.178 & 2.915 & 5.607 & 21.491 & 12.596 & 12.356 & 4.821 \\
\hline & & -0.664 & 1.703 & 0.839 & 0.745 & 0.679 & -0.385 & 2.574 & 1.222 & 1.160 & 0.988 \\
\hline & & -0.191 & 4.562 & 2.171 & 1.961 & 1.528 & 3.437 & 11.681 & 7.254 & 6.758 & 2.496 \\
\hline \multirow{8}{*}{$\begin{array}{c}\text { Cluster } \\
2\end{array}$} & Croatia & -2.044 & 4.081 & 1.369 & 1.282 & 1.579 & 0.797 & 4.539 & 1.913 & 2.285 & 1.165 \\
\hline & Estonia & -0.181 & 2.459 & 0.591 & 0.839 & 0.760 & -1.329 & 3.933 & 2.092 & 1.772 & 1.635 \\
\hline & Lithuania & -0.237 & 1.407 & 0.257 & 0.417 & 0.485 & 0.269 & 1.827 & 1.099 & 1.222 & 0.512 \\
\hline & Latvia & -0.031 & 1.431 & 0.592 & 0.607 & 0.415 & -0.233 & 1.647 & 1.172 & 0.956 & 0.692 \\
\hline & Hungary & 0.177 & 4.985 & 3.017 & 2.727 & 1.345 & -150.4 & 135.359 & -6.883 & -5.577 & 70.750 \\
\hline & Poland & 1.759 & 16.748 & 10.933 & 11.149 & 4.882 & 0.032 & 35.306 & 22.816 & 20.895 & 10.461 \\
\hline & Slovak Republic & -0.789 & 3.010 & 0.442 & 0.821 & 1.366 & -0.065 & 10.089 & 3.771 & 4.536 & 3.467 \\
\hline & Average of cluster & 1.110 & 4.027 & 2.601 & 2.549 & 0.947 & -18.19 & 25.610 & 3.192 & 3.727 & 10.775 \\
\hline \multirow{3}{*}{$\begin{array}{c}\text { Cluster } \\
\mathbf{3}\end{array}$} & Bulgaria & 0.135 & 3.543 & 1.592 & 1.687 & 0.966 & 1.899 & 4.265 & 2.491 & 2.793 & 0.755 \\
\hline & Romania & 2.275 & 5.606 & 4.336 & 4.195 & 1.073 & 2.389 & 7.597 & 4.761 & 4.990 & 1.687 \\
\hline & & 1.920 & 4.649 & 2.844 & 2.997 & 0.900 & 2.469 & 5.619 & 3.895 & 3.892 & 1.046 \\
\hline
\end{tabular}

Source: World Bank, Global Development Finance: Country Tables, period 2009-2018. Prepared by authors. 
- differences in percentage of investments, domestic savings, consumption and current accounts of each cluster in net and gross capital flows, FDIs and portfolio investments are presented.

In the literature, it is commonly held that a country's savings tend to be largely invested within its borders; if almost all domestic savings are invested domestically in a country's economy, the international capital inflows will not be substantially offset by international capital outflows and, in the end, gross domestic investment will account for almost the full amount of inflows.

The three clusters of countries reveal quite different effects of inflows on capital flows.

However, because the globalization of the countries' economies is increasing rapidly, we anticipate that the link between foreign flows and domestic investment will weaken in the future. Looking from another perspective, structural factors in the country, such as the level of human capital or the depth of financial markets, may also influence the relationship between the country's foreign capital and investments. A more developed country could use one euro of foreign capital more effectively than a less integrated one.

There are various studies on foreign capital's impact on domestic investment or savings. It has been argued that one euro of capital inflow could be equal to one euro in domestic investment. Another argument is that one euro of FDI may increase the domestic investments of more than euro, and so on. Bosworth and Collins (1999) analysed the relationship between private capital flows and both investment and savings. They concluded that "capital flows have a strong impact on domestic investment. This is especially so for FDI and bank lending; in contrast, portfolio flows have a positive, but statistically insignificant impact on domestic investment". This is supported by Figure 3, which shows how inflows in a cluster's capital flows, FDIs and portfolio investments influence countries' investments, domestic savings, current accounts and consumption if GDP change in one percent. investments in cluster 1 (composed of highly developed countries: the Czech Republic and Slovenia).

One inflow in net capital flows would positively affect all categories, from $0.7 \%$ for current accounts to around $12 \%$ for consumption. One inflow in gross capital flows would have positive effects, from $0.20 \%$ for current accounts and $0.44 \%$ for investments (barely visible in Figure 3 ) to $13.58 \%$ for consumption. One inflow in FDIs would mostly affect domestic savings $(11.02 \%)$. It would have only a $0.04 \%$ impact on consumption. Domestic savings, investments, consumption and current accounts would be negatively affected by one inflow in short-term flows: portfolio investments. The impact would be from $-0.59 \%$ on current accounts to $-19 \%$ on consumption.

In contrast to cluster 1 , we can see positive growth in investments, domestic savings and consumption caused by one inflow in all capital categories in cluster 2 (composed of seven developing countries; see Table 5).

Change in current accounts would be around $-0.01 \%$ in all inflow categories; this is barely visible in Figure 3. Investments would change from $0.61 \%$ (caused by inflow in gross capital flows) to $4.10 \%$ (caused by inflow in portfolio investments). One inflow in net capital flows would influence the positive growth of consumption $(15.75 \%)$. The impact on domestic savings would be around $10 \%$ on investments $(1 \%)$. Inflow in gross capital flows would affect consumption (17.82\%) and domestic savings (7.18\%). One inflow in FDIs would increase $(19.17 \%)$ consumption in cluster 2 (see Figure 3). One inflow in portfolio investments would result in the highest changes in consumption (12.75\%) and domestic savings (around $11.42 \%$ ); this also differs from cluster 1, in which investments, domestic savings, consumption and current accounts would change negatively.

The relationships between cluster 3's (composed of emerging market countries - Bulgaria's and Romania's) capital flows and investments, domestic savings, consumption and current accounts are different again from the other two clusters.

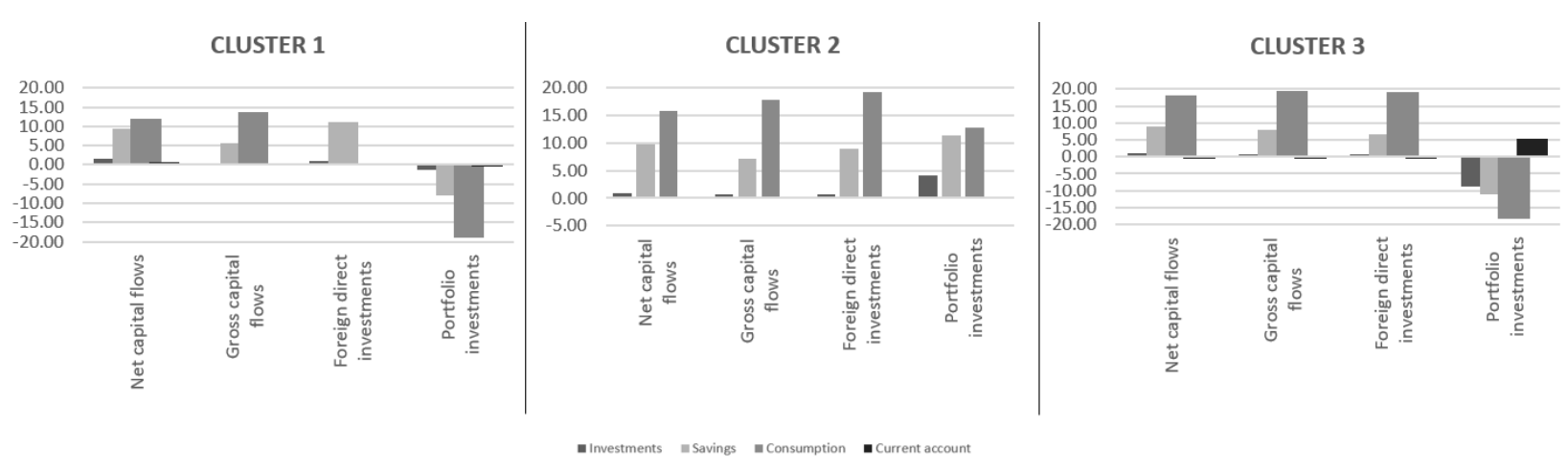

Figure 3. The impact of capital flows on investment, domestic savings, consumption and current accounts. Computed coefficients representing the change associated with an increase in clusters' capital inflow equal to a 1 percent increase of GDP

Source: World Bank, Global Development Finance: Country Tables, period 2009-2018. Prepared by authors.

Figure 3 presents the impact of capital flows on investment, domestic savings, consumption and current accounts. As we can see, the impact on domestic savings and consumption would be significantly higher than on 
One inflow in gross capital flows and FDIs would influence similar growth of consumption (around 19.30\%) and domestic savings $(6.48-7.90 \%)$. One inflow in net capital flows would cause an increase of $17.97 \%$ for consumption and $8.91 \%$ for domestic savings. One inflow in short-term flows - portfolio flows - would significantly and negatively influence investments, domestic savings and consumption while affecting current accounts positively $(5.49 \%)$. The change in investments would be from $-8.73 \%$ (caused by inflow in portfolio investments) to $0.71 \%$ (caused by inflow in FDIs).

The main findings: how positive inflows (equal to a $1 \%$ decrease of GDP) in clusters' net and gross capital flows, FDIs and portfolio investments affect countries' investments, domestic savings, consumption, and current accounts could be excluded:

- First, domestic savings and consumption would be affected significantly positively than investments in all inflow categories in developed countries (cluster 2).

- Second, investments, domestic savings and consumption would be negatively affected by one inflow in short-term flows, such as portfolio flows, in both highly developed countries (cluster 1) and emerging market countries (cluster 3 ), while current accounts would increase in emerging market countries (cluster 3).

- Third, inflows in capital flows (such as net and gross capital, FDIs) would have an insignificant positive impact on current accounts in highly developed countries (cluster 1) and developed countries (cluster 2) and a negative impact in emerging countries (cluster 3 ).

Different results could be obtained if capital inflows were negative and equal to a 1 percent decrease of GDP (e.g. when a country's economic cycle is slowing). As we can see from Figure 4, the negative impact on domestic savings and
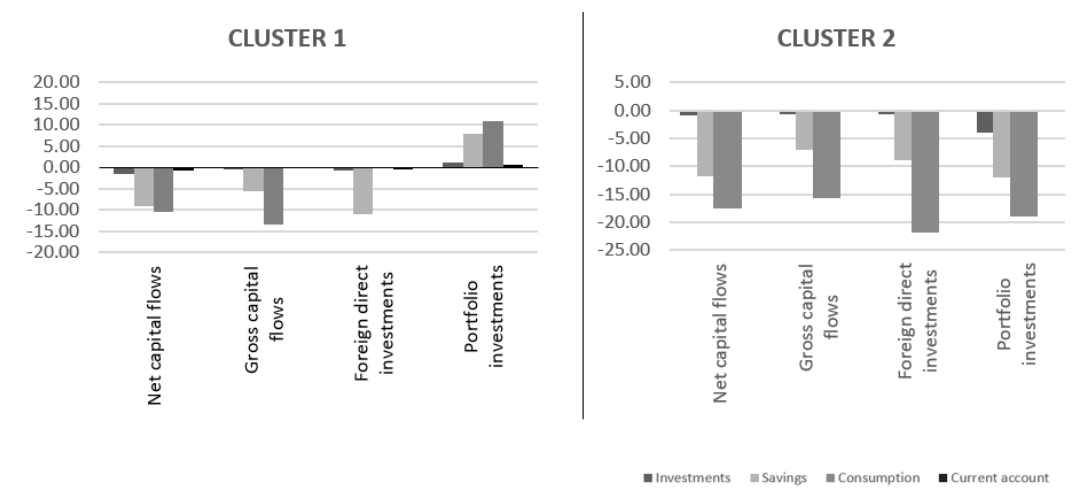

Figure 4. The Impact of Capital Flows on Investment, Domestic Savings, Consumption and Current Accounts. Computed Coefficients Representing the Change Associated With a Decrease in Clusters' Capital Inflow Equal to a 1 Percent Decrease of GDP

Source: World Bank, Global Development Finance: Country Tables, period 2009-2018. Prepared by authors

One inflow net in and gross capital flows would negatively affect consumption (from $-10.49 \%$ to $-13.41 \%$ ) and domestic savings ( $-5.53 \%$ (affected by gross capital flows) to $-9.13 \%$ (affected by net capital flows)). Decrease of investments would be from $-0.43 \%$ (caused by gross capital flows and barely visible in the graphic) to $1.24 \%$ (caused by short-term flows: portfolio investments). One negative inflow in FDIs would mostly affect domestic consumption would be significantly higher than on investments in cluster 1 .

Investments, domestic savings, consumption and current accounts would be positively affected by 1 negative inflow in short-term flows: portfolio investments. The impact would be from $0.58 \%$ for current accounts to $10.80 \%$ for consumption.

Analyses of cluster 2 reveals different results. Here, decrease of inflows would mostly affect consumption in all capital flows categories. The reflection of consumption would be from $-15.64 \%$ (caused by decrease in gross capital flows) to $-21.95 \%$ (caused by a decrease in FDIs). Investments' would reflect to such a situation from $-0.60 \%$ (caused by a decrease in gross capital flows) to $-4.06 \%$ (caused by a decrease in portfolio investments). The impact on domestic savings would mostly change also in these capital flows categories: from $-7.11 \%$ (caused by a decrease in gross capital flows) to $-11.94 \%$ (caused by decrease in portfolio investments). In cluster 2 , current account changes remain the same at around $0.01 \%$.

Analyses of cluster 3 show that the change in investments would be from $-0.71 \%$ (caused by inflow in FDIs) to $8.65 \%$ (caused by inflow in portfolio investments). A decrease of one inflow in gross and net capital flows and FDIs would result a decrease in consumption (from -17.08 to $-20.00 \%$ ) and domestic savings (from -6.42 to $-7.82 \%$ ). One negative inflow in short-term flows (portfolio flows) would significantly and positively influence investments, domestic savings and consumption while negatively influencing current accounts $(-5.43 \%)$. The reflection of consumption would be $21.00 \%$, investments and domestic savings would change from $8.65 \%$ to $10.39 \%$. 
- First, domestic savings and consumption would be affected significantly negatively than investments in all inflow categories in developed countries (cluster 2).

- Second, investments, domestic savings and consumption would be positively affected by one inflow in short-term flows, such as portfolio flows, in both highly developed countries (cluster 1) and emerging market countries (cluster 3 ) while current accounts would decrease in emerging market countries (cluster 3).

- Third, inflows in capital flows (like the net and gross capital, FDIs) would have an insignificant negative impact on current accounts in highly developed countries (cluster 1) and developed countries (cluster 2) and a positive impact in emerging countries (cluster 3 ).

The analyses show that it is important to rapidly and comprehensively evaluate capital flows because it can affect a country's economy and have an impact on their growth.

\section{Conclusions}

A comprehensive review of the literature shows that there is no consensus on the relationship between international capital flows and economic growth, nor on the most appropriate models to assess the effect of international capital flows on a country's economic development. To fill this gap, this paper analysed the impact of international capital flows on countries' investments, savings, consumption and current accounts. In support of some existing research, it can be said that countries that change their capital controls and measures (i.e. pay closer attention to these) experience different outcomes than countries that do not. There is a huge difference between developing and growing economies. International capital flows may affect a country's economy and cause financial imbalances, so it is in the interest of policymakers and national governments to pay attention and seek to manage capital flows.

It is worth reiterating that previous research does not cover all related costs nor identify similarities between countries. This paper set out to do these things, and the analyses conducted demonstrate that it is beneficial to identify similarities between selected countries and clusters - the different effects of international capital flows can be identified. Gross flows show that the global financial crisis period (2008-9) led to short-term (rather than long-term) change in capital flows CEE economies.

The governments of countries seek economic growth. Unfortunately, according to the banks' prognosis, GDP growth rates will decrease in the future, and this will have an impact on national economies.

The main findings: how positive/negative inflows (equal to $1 \%$ increase or decrease of GDP) in clusters' net and gross capital flows, FDIs and portfolio investments affect countries' investments, domestic savings, consumption, and current accounts, could be excluded:

- First, domestic savings and consumption are seen to have been more strongly associated with capital inflows than investments in developed countries (cluster 2).

- Second, the relationship between investments, domestic savings, consumption and one inflow in short-term flows, such as portfolio flows, would be negative, in both highly developed countries (cluster 1) and emerging market countries (cluster 3) if GDP increases, and would be positively affected if GDP decreases.

- Third, inflows in capital flows (such as net and gross capital, FDIs) would have an insignificant positive impact on current accounts in highly developed countries (cluster 1) and developed countries (cluster 2) and a negative impact in emerging countries (cluster 3 ); the opposite would be true if GDP decreased.

The results of this research may be useful for other EU countries as well because changes in one area of the EU will have an impact on the other areas owing to interconnectedness and integration. For example, countries could find apply the results of the most similar of the three clusters in this research to themselves. By achieving economic growth dynamics in a specific country, evaluation and control of a country's capital flows can be performed by applying different assessment models.

\section{References}

Alfaro, L., \& Chauvin, J. (2017). Foreign Direct Investment, Finance, and Economic Development. Chapter for the Encyclopedia of International Economics and Global Trade, Forthcoming. Available at: https://ssrn.com/ abstract $=2908440$.

Beirne, J., \& Friedrich, C. (2014). Capital Flows and Macroprudential Policies: A Multilateral Assessment of Effectiveness and Risks. European Central Bank working paper series, No. 1721. Available at: https://www.ecb.europa.eu/ pub/pdf/scpwps/ecbwp1721.pdf.

Bluedorn, J., Duttagupta, R., Guajardo, J., \& Topalova, P. (2013). Capital Flows are Fickle: Anytime, Anywhere. IMF Working Paper, No. WP/13/183. Available at: https://www.tcd.ie/Economics/assets/pdf/John\%20Bluedorn \%20et\%20al.pdf. https://doi.org/10.5089/9781484389041.001

Borio, C., \& Disyatat, P. (2015). Capital Flows and the Current Account: Taking Financing (More) Seriously. BIS Working Paper, No. 525. Available at: https://www.bis.org/publ/work525.pdf.

Bosworth, B., \& Collins, S. M. (1999). Capital Flows to Developing Economies: Implications for Saving and Investment. Brookings Papers on Economic Activity, 30, 143-180. Available at: https://econpapers.repec.org/article/ binbpeajo/v_3a30_3ay_3a1999_3ai_3a1999-1_3ap_3a143-180.htm.

Bussiere, M., \& Fratzscher, M. (2008). Financial Openness and Growth: Short-run Gain, Long-run Pain? Review of International Economics, 16(1), 69-95. Available at: https://econpapers.repec.org/article/blareviec/v_3a16_ 3ay_3a2008_3ai_3a1_3ap_3a69-95.htm. https://doi.org/10.1111/j.1467-9396.2007.00727.x 
Laura Vilutiene, Daiva Dumciuviene. The Impact of International Capital Flows on Central and Eastern European ...

Carkovic, M., \& Levine, R. (2002). Does Foreign Direct Investment Accelerate Economic Growth? University of Minnesota Department of Finance Working Paper. Available at: http://ssrn.com/abstract $1 / 4314924$. https://doi.org/10. 2139/ssrn.314924

Durham, J. B. (2004). Absorptive Capacity and the Effects of Foreign Direct Investment and Equity Foreign Portfolio Investment on Economic Growth. European Economic Review, 48, 285-306. Available at: https://econpapers.repec.org/article/eeeeecrev/v_3a48_3ay_3a2004_3ai_3a2_3ap_3a285-306.htm. https://doi.org/10.1016/S0014-2921(02)00264-7

Edwards, S., \& Rigobon, R. (2009). Capital Controls on Inflows, Exchange Rate Volatility and External Vulnerability. Journal of International Economics, 78, 256-267. Available at: https://www.researchgate.net/ publication/222564947_Capital_Controls_on_Inflows_Exchange_Rate_Volatility_and_External_Vulnerability. https://doi.org/10.1016/j.jinteco.2009.04.005

European Commission (2014). Research and Innovation Performance in the EU: Innovation Union progress at the country level. Available at: http://ec.europa.eu/research/innovation-union/pdf/state-of-the-union/2014/iuc_progress_ report_2014.pdf.

European Union (2015). Sustainable development in the European Union - 2015 monitoring report of the EU Sustainable Development Strategy. Available at: https://ec.europa.eu/eurostat/web/products-statistical-books/-/KS-GT-15-001.

Forbes, K., Fratzscher, M., \& Straub, R. (2015). Capital-flow Management Measures: What Are They Good For? Journal of International Economics, 96(1), S76-S97. Available at: https://www.researchgate.net/publication/270968216 Capital-Flow_Management_Measures_What_Are_They_Good_For. https://doi.org/10.1016/j.jinteco.2014.11.004

Forbes, K., \& Warnock, F. E. (2012). Capital Flow Waves: Surges, Stops, Flight, and Retrenchment. Journal of International Econonomics, 88, 235-251. Available at: https://econpapers.repec.org/article/eeeinecon/ v_3a88_3ay_3a2012_3ai_3a2_3ap_3a235-251.htm. https://doi.org/10.1016/j.jinteco.2012.03.006

Harrison, A. E., Love, I., \& McMillian, M. S. (2004). Global Capital Flows and Financing Constraints. Journal of Development Economics, 75, 269-301. Available at: https://econpapers.repec.org/article/eeedeveco/ v_3a75_3ay_3a2004_3ai_3a1_3ap_3a269-301.htm. https://doi.org/10.1016/j.jdeveco.2003.10.002

Hermes, N., \& Lensink, R. (2003). FDI, Financial Development and Growth. Journal of Development Studies, 40, 142163. Available at: https://econpapers.repec.org/article/tafjdevst/v_3a40_3ay_3a2003_3ai_3a1_3ap_3a142163.htm. https://doi.org/10.1080/00220380412331293707

Klein, M. W., \& Olivei, G. (2008). Capital Account Liberalization, Financial Depth and Economic Growth. NBER Working Paper, No. 7384. Available at: https://econpapers.repec.org/paper/nbrnberwo/7384.htm.

Kyaw, K. S., \& Macdonald, R. (2009). Capital Flows and Growth in Developing Countries: A Dynamic Panel Data Analysis. Oxford Development Studies, 37(2). Available at: https://www.researchgate.net/publication/ 23528719_Determinants_of_Capital_Flows_to_Developing_Countries_A_Structural_VAR_Analysis. https://doi.org/10.1080/13 $\overline{3} \overline{0} 081090 \overline{2} 85953 \overline{6}$

Levine, R. (2001). International Financial Liberalization and Growth. Review of International Economics, 9, 688-702. Available at: https://econpapers.repec.org/article/blareviec/v_3a9_3ay_3a2001_3ai_3a4_3ap_3a688-702.htm. https://doi.org/10.1111/1467-9396.00307

Lucas, R. E. (1988). On the Mechanics of Economic Development. Journal of Monetary Economics, 22, 3-42. Available at: https://www.sciencedirect.com/science/article/abs/pii/0304393288901687. https://doi.org/10.1016/0304-3932 (88) $90168-7$

Lucas, R. E. (1990). Why Doesn't Capital Flow from Rich to Poor Countries? American Economic Review, 80, 92-96. Available at: https://econpapers.repec.org/article/aeaaecrev/v_3a80_3ay_3a1990_3ai_3a2_3ap_3a92-96.htm.

Mankiw, N. G., Romer, D., \& Weil, D. N. (1992). A Contribution to the Empirics of Growth. Quarterly Journal of Economics, 107, 407-437. Available at: https://eml.berkeley.edu/ dromer/papers/MRW_QJE1992.pdf. https://doi.org/10.2307/2118477

Pack, H. (1994) Endogenous Growth Theory: Intellectual Appeal and Empirical Shortcomings. Journal of Economic Perspectives, 8, 55-72. Available at: https://econpapers.repec.org/article/aeajecper/v_3a8_3ay_3a1994_3ai_ 3a1_3ap_3a55-72.htm. https://doi.org/10.1257/jep.8.1.55

Qureshi, M. S., Ostry, J. D., Ghosh, A. R., \& Chamon, M. (2011). Managing Capital Inflows: The Role of Capital Controls and Prudential Policies. NBER Working Paper, No. 17363. Available at: https://econpapers.repec.org/ paper/nbrnberwo/17363.htm. https://doi.org/10.3386/w17363

Rey, H. (2015). Dilemma Not Trilemma: The Global Financial Cycle and Monetary Policy Independence. NBER Working Paper, No. 21162. Available at: https://www.nber.org/papers/w21162. https://doi.org/ 10.3386/w21162 
Romer, P. M. (1986). Increasing Returns and Long Run Growth. Journal of Political Economy, 94, 1002-1037. Available at: http://www.dklevine.com/archive/refs42232.pdf. https://doi.org/10.1086/261420

Romer, P. M. (1990) Endogenous Technological Change. Journal of Political Economy, 98, s71-s102. Available at: http://pages.stern.nyu.edu/ promer/Endogenous.pdf. https://doi.org/10.1086/261725

Romer, P. M. (1993) Idea Gaps and Object Gaps in Economic Development. Journal of Monetary Economics, 32, $543-$ 573. Available at: https://www.sciencedirect.com/science/article/abs/pii/030439329390029F. https://doi.org/10. 1016/0304-3932(93)90029-F

Velde, D. W., \& Xenogiani, T. (2007). Foreign Direct Investment and International Skill Inequality. Oxford Development Studies, 35, 83-104. Available at: https://www.researchgate.net/publication/24085799_Foreign_Direct_ Investment_and_International_Skill_Inequality. https://doi.org/10.1080/13600810601167603

Wei, S. J. (2018). Managing Financial Globalization: A Guide for Developing Countries Based on the Recent Literature. ADBI Working Paper Series, No. 804. Available at: https://www.adb.org/sites/default/files/ publication/399286/ adbi-wp804.pdf. https://doi.org/10.2139/ssrn.3140101

The article has been reviewed.

Received in December 2019; accepted in October 2020.

This article is an Open Access article distributed under the terms and conditions of the Creative Commons Attribution 4.0 (CC BY 4.0) License (http://creativecommons.org/licenses/by/4.0/). 